\title{
ANALISIS KEMAMPUAN PEMECAHAN MASALAH MATEMATIKA EKONOMI DITINJAU DARI KEMAMPUAN BERPIKIR LOGIS PADA MAHASISWA
}

\author{
Wahyuddin \\ Fakultas Keguruan dan Ilmu Pendidikan Universitas Muhammadiyah Makassar \\ Jalan Sultan Alauddin No. 259 Makassar \\ wahyu@unismuh.ac.id
}

\begin{abstract}
ABSTRAK
Penelitian ini bertujuan untuk mengetahui tingkat kemampuan berpikir logis, kemampuan penyelesaian masalah matematika ekonomi, dan pengaruh kemampuan berpikir logis terhadap kemampuan penyelesaian masalah matematika ekonomi pada mahasiswa Jurusan Pendidikan Matematika Universitas Muhammadiyah Makassar. Jenis penelitian ini adalah ex-post facto yang bersifat kausalitas dengan populasi 245 orang dari 8 kelas yang berbeda. Sampel diambil sebanyak 58 orang mahasiswa yang terdiri dari 2 kelas, teknik pengambilan sampel yaitu pengambilan sampel secara acak berkelompok. Instrumen penelitian terdiri atas tes kemampuan berpikir logis sebanyak 30 butir soal dan tes kemampuan pemecahan masalah sebanyak 5 butir soal yang dinyatakan valid dan reliabel sebelum digunakan. Data dianalisis dengan menggunakan statistika deskriptif dan analisis inferensial (Analisis korelasi dan regresi). Hasil penelitian menunjukkan bahwa: (1) Tingkat kemampuan berpikir logis masiswa berada pada kategori cukup baik dengan nilai rata-rata 69,13 ; (2) Tingkat kemampuan penyelesaian masalah matematika ekonomi bagi masiswa berada pada kategori cukup baik dengan nilai rata-rata 74,03; (3) Tingkat kemampuan berpikir logis masiswa memiliki korelasi dengan kemampuan penyelesaian masalah matematika ekonomi dengan besar hubungan 94,5\% dimana hal tersebut berada pada baik sekali; dan (5) Kemampuan berpikir logis berpengaruh positif terhadap kemampuan penyelesaian masalah dengan pengaruh sebesar $89,1 \%$ sedangkan sisanya sebesar $10,9 \%$ dipengaruhi oleh variabel lain di luar model. Kemampuan berpikir logis berpengaruh positif terhadap kemampuan kemampuan penyelesaian, hal tersebut dapat diartikan bahwa semakin baik atau semakin tinggi kemampuan berpikir logis yang dimiliki oleh mahasiswa maka kemampuan penyelesaian masalah mahasiswa tersebut akan semakin baik atau semakin tinggi.
\end{abstract}

Kata Kunci : Kemampuan Berpikir Logis, Kemampuan Pemecahan Masalah, Matematika Ekonomi.

\begin{abstract}
This study aims to determine the level of logical thinking skills on math problem solving ability of the economy, and the effect on the ability of logical thinking ability of solving mathematical economics at Mathematics Education students Muhammadiyah University Makassar. This research is an ex-post facto nature of causality with total population of 245 people from 8 different classes. Samples invoved 58 students consisting of 2 classes using a sampling technique that randomly sampling groups. The research instrument consists of logical thinking ability test as many as 30 items and problem solving test ability by 5 items were valid and reliable before use. Data were analyzed using descriptive and inferential statistics (correlation and regression analysis). The research findings shows that: (1) The ability to think logically masiswa are in good enough category with an average value of 69.13 ; (2) The level of mathematical problem solving ability for masiswa economy is in the category quite well with the average value of 74.03; (3) The level of logical thinking ability masiswa correlated with mathematical problem solving ability with great economy of $94.5 \%$ relationship where that is located on a well once; and (5) the ability to think logically positive effect on the ability of solving problems with the effect of $89.1 \%$ while the remaining $10.9 \%$ is influenced by other variables outside the model. On conslusion, the ability to think logically positive effect on the ability of settlement capability, it can be concluded that the
\end{abstract}


higher of logical thinking skills possessed by the student means the student problem-solving abilities are higher.

Keywords: Logical Thinking Skills, Problem Solving Ability, Mathematical Economics.

\section{Pendahuluan}

Undang-Undang Nomor 14 Tahun 2005 tentang Guru dan Dosen Guru wajib memiliki kualifikasi akademik, kompetensi, sertifikat pendidik, sehat jasmani dan rohani, serta memiliki kemampuan untuk mewujudkan tujuan pendidikan nasional. Kompetensi guru sebagaimana dimaksud dalam Pasal 8 meliputi kompetensi pedagogik, kompetensi kepribadian, kompetensi sosial, dan kompetensi profesional yang diperoleh melalui pendidikan profesi.

Mengingat mahasiswa pendidikan matematika adalah calon guru matematika yang ke depannya akan bertindak sebagai pendidik dan pengajar matematika, maka masiswa pendidikan matematika juga harus dipersiapkan untuk menguasai keempat komptensi guru yang dimaksud sebelum mereka menjadi guru yang sebanrnya. Mahasiswa calon guru matematika mempunyai peran penting dalam menentukan keberhasilan di masa akan datang dalam pencapaian hasil belajar siswanya, sehingga mahasiswa calon guru matematika perlu dibekali dengan pengalaman yang cukup dan pengetahuan yang lebih baik dan memadai.

Analisis ... (Wahyuddin)
Committee on the Undergraduate Program in Mathematics (CUPM, 2004) merekomendasikan untuk program studi matematika dan perkuliahan matematika, serta calon guru matematika yang meliputi enam rekomendasi penting untuk pengembangan pembelajaran matematika yaitu setiap perkuliahan hendaknya melibatkan kegiatankegiatan yang dapat membantu memajukan mahasiswa dalam mengembangkan berpikir anilitik, bernalar kritis, memecahkan masalah, dan keterampilan berkomunikasi serta membiasakan berpikir matematik; menyajikan ide-ide dan konsep kunci dari berbagai perspektif; menggunakan contoh-contoh dan penerapan yang luas untuk memotivasi dan mengilustrasikan materi; mempromosikan kesadarankesadaran tentang kaitan-kaitan matematika dengan subjek lain dari matematika atau di luar matematika; memperkenalkan topik-topik kontemporer dari matematika dan penerapannya, dan meningkatkan persepsi mahasiswa tentang pentingnya matematika dalam dunia modern. 
Lebih lanjut, khusus untuk calon guru matematika, CUPM (2004) merekomendasikan agar perkuliahan dapat membantu mahasiswa untuk mengembangkan: (1) Pengetahuan yang solid pada level atas; (2) Berpikir matematik dan keterampilanl komunikasi, termasuk pengetahuan beragam penjelasan dan contoh, keterampilan berpikir kuantitatif dan logis yang baik dalam memisahkan dan menghubungkan kembali bagian-bagian komponen konsep dan metode; (3) Pemahaman dan pengalaman dengan penggunaan matematika dalam berbagai lapangan; dan (4) Pengetahuan, kepercayaan diri dan motivasi untuk mengejar perkembangan matematika profesional untuk karir jangka panjang.

Dari rekomendasi tersebut dapat disimpulkan bahwa mahasiswa calon guru harus dibekali dengan sejumlah kompetensi baik berupa kecakapan matematik (mathematical abilities), pemahaman materi yang mendalam dan komprehensip (contens strands) dan terutama kemampuan-kemampuan proses (process standards), kemampuan pemecahan masalah dan kemampuan berpikir logis.

Kemampuan pemecahan masalah amatlah penting dalam matematika, bukan saja bagi mereka yang di kemudian hari akan mendalami atau mempelajari matematika, melainkan juga bagi mereka yang akan menerapkannya dalam bidang studi lain dan dalam kehidupan sehari-hari (Russefffendi, 2006). Kemampuan pemecahan masalah matematis adalah suatu keterampilan pada diri peserta didik agar mampu menggunakan kegiatan matematik untuk memecahkan masalah dalam matematika, masalah dalam ilmu lain dan masalah dalam kehidupan sehari-hari. Sumarmo berpendapat bahwa pemecahan masalah adalah suatu proses untuk mengatasi kesulitan yang ditemui untuk mencapai suatu tujuan yang diinginkan.

\section{National Council of Teachers of} Mathematics menetapkan pemecahan masalah sebagai suatu tujuan dan pendekatan. Memecahkan masalah bermakna menjawab suatu pertanyaan dimana metode untuk mencari solusi dari pertanyaan tersebut tidak dikenal terlebih dahulu. Untuk menemukan suatu solusi, siswa harus menggunakan hal -hal yang telah dipelajari sebelumnya dan melalui proses dimana mereka akan mengembangkan

pemahamanpemahaman matematika baru. Memecahkan masalah bukanlah hanya suatu tujuan dari belajar matematika tetapi sekaligus merupakan alat utama 
untuk melakukan proses belajar itu (NCTM, 2000).

\section{Kemampuan}

masalah

merupakan

pemecahan

suatu

kemampuan yang sangat dibutuhkan oleh mahasiswa. Sumarmo (2000) mengemukakan bahwa, pemecahan masalah adalah suatu proses untuk mengatasi kesulitan yang ditemui untuk mencapai suatu tujuan yang diinginkan. Kemampuan pemecahan masalah dapat ditumbuhkan melalui aktivitas penyelesaian masalah. Hal ini untuk memudahkan mahasiswa dalam mengaitkan pengetahuan yang diperoleh dengan pengalamannya. Jika masalah tidak berkaitan dengan pengalaman mahasiswa, maka mereka belum tentu dapat memahami masalah yang dipelajari dengan baik. Pemecahan masalah harus selalu dibiasakan bagi mahasiswa dalam rangka mencapai tujuan yang diinginkan. Namun demikian, seorang mahasiswa tidak akan dapat memecahkan suatu masalah yang diberikan kepadanya apabila tidak memiliki konsep-konsep sebelumnya yang dibutuhkan. Pentingnya kemampuan pemecahan masalah dikemukan juga oleh Soedjadi (dalam Kisworo, 2000), bahwa keberhasilan seseorang dalam kehidupannya banyak Analisis ... (Wahyuddin) ditentukan oleh kemampuan untuk memecahkan masalah yang dihadapinya.

Pemecahan masalah sebagai salah satu aspek kemampuan berpikir tingkat tinggi. Polya menyatakan bahwa pemecahan masalah merupakan suatu tingkat aktivitas intelektual yang sangat tinggi. Pemecahan masalah adalah suatu aktivitas intelektual untuk mencari penyelesaiaan masalah yang dihadapi dengan menggunakan bekal pengetahuan yang sudah dimiliki. Pendapat tersebut didukung oleh pernyataan Branca (dalam Sumarmo, 1994) bahwa kemampuan pemecahan masalah merupakan tujuan umum dalam perkuliahan matematika, bahkan sebagai jantungnya matematika, artinya kemampuan pemecahan masalah merupakan kemampuan dasar dalam kuliah matematika.

Menurut Jhon (2008: 5), indikator pemecahan masalah adalah : a) Membangun pengetahuan matematika melalui pemecahan masalah; b) Menyelesakan soal yang muncul dalam matematika; c) Menerapkan dan menyesuaikan berbagai macam strategi yang cocok untuk memecahkan soal; dan d) Mengamati dan mengembangkan proses pemecahan masalah matematika.

Beberapa indikator pemecahan masalah dapat diperhatikan dari paparan Sumarmo (2003), adalah sebagai berikut: AdMathEdu | Vol.7 No.2 | Desember 2017 
a) Mengidentifikasi unsur-unsur yang diketahui, yang ditanyakan, dan kecukupan unsur yang diperlukan; b) merumuskan masalah matematika atau menyusun model matematika; menerapkan strategi untuk menyelesaikan berbagai masalah (sejenis dan masalah baru) dalam atau di luar matematika; c) menjelaskan atau menginterpretasikan hasil sesuai permasalahan asal, dan d) Menggunakan matematika secara bermakna.

Terdapat 4 tahapan problem solving menurut Polya (dalam Alexanderson, 2000), antara lain :

1. Understanding the problem (Memahami masalah)

Langkah awal dalam tahapan yang diajukan oleh Polya ini adalah membaca masalah dan memastikan bahwa siswa memahami dengan jelas masalah yang diajukan oleh guru. Ditahap awal ini, ada beberapa hal yang perlu diperhatikan, antara lain : (a) Apakah semua kata-kata yang digunakan dapat dipahami dengan jelas?; (b) Apa yang tidak diketahui? Apa saja datanya? Bagaimana kondisinya?; (c) Dapatkah siswa mengemukakan kembali masalah yang diajukan tersebut dengan; (d) Menggunakan kata-kata mereka sendiri?; (e) Apakah informasi yang dimiliki oleh siswa telah cukup sehingga memungkinkan untuk ditemukannya solusi yang tepat? (f) Dapatkah dibuat gambar atau menemukan notasi yang cocok untuk membantu dalam memahami masalah ?

2. Devising a plan (Merencanakan Penyelesaian)

$$
\text { Polya menyebutkan bahwa }
$$
banyak cara untuk memecahkan masalah. Keterampilan dalam memilih strategi yang tepat paling baik dipelajari dengan menyelesaikan banyak masalah. Siswa akan menemukan strategi yang tepat dengan gampang apabila telah banyak memecahkan masalah-masalah. Adapun hal-hal yang perlu diperhaatikan dalam tahap kedua ini antara lain: a) Menemukan hubungan antara informasi yang diberikan dan yang tidak diketahui yang akan memungkinkan siswa untuk menghitung diketahui. Carilah hubungan antara data dan hal yang tidak diketahui; b) Apakah siswa pernah melihatnya sebelumnya? Atau apakah siswa pernah melihat masalah yang sama dalam bentuk yang sedikit berbeda?; c) Apakah siswa tahu masalah yang berkaitan? Apakah siswa tahu teorema yang dapat berguna?; d) Cobalah memikirkan masalah yang sudah biasa dihadapi.

3. Carrying out the plan (Melaksanakan penyelesaikan masalah sesuai rencana). 
Langkah ini biasanya lebih mudah dibandingkan daripada menyusun rencana. Secara umum, yang dibutuhkan adalah perhatian dan kesabaran, mengingat siswa telah memiliki keterampilan yang diberikan. Lakukan dengan tepat rencana yang telah disusun. Kalau ternyata rencana ini tidak tepat karena tidak dapat ditemukan solusi yang tepat, maka pilihlah rencana lain. Jangan berputus asa dulu, karena begitulah cara memecahkan matematika. Hal yang harus diperhatikan dalam tahap ini adalah dapatkah siswa melihat dengan jelas bahwa langkah yang dijalankannya telah benar? Bisakah siswa membuktikan bahwa itu benar?

\section{Looking back (Melihat kembali penyelesaian atau memeriksa kembali)}

Polya menyebutkan bahwa banyak yang bisa diperoleh dengan merenungkan dan melihat kembali pada apa yang telah siswa lakukan ini. Hal-hal penting yang bisa dikembangkan dalam langkah terakhir ini antara lain : mencari kemungkinan adanya generalisasi, melakukan pengecekan terhadap hasil yang diperoleh, mencari cara lain untuk menyelesaikan masalah yang sama, mencari kemungkinan adanya penyelesaian lain, dan dalam menelaah kembali proses penyelesaian masalah Analisis ... (Wahyuddin) yang telah dibuat. Siswa diharapkan agar bisa menggunakan kalimat yang lengkap dan tepat untuk menyimpulkannya setelah mengetahui bahwa jawabannya telah tepat. Melakukan hal ini akan memungkinkan siswa untuk memprediksi strategi apa yang digunakan untuk memecahkan masalah pada permasalahan nantinya. Memikirkan atau menelaah kembali langkah-langkah yang telah dilakukan dalam pemecahan masalah merupakan kegiatan yang sangat penting untuk meningkatkan kemampuan anak dalam pemecahan masalah.

Selain kemampuan pemecahan masalah, kemampuan berpikir logis juga merupa aspek yang penting bagi mahasiswa dalam belajar matematika. kemampuan berpikir logis (penalaran), yaitu kemampuan menemukan suatu kebenaran berdasarkan aturan, pola atau logika tertentu (Suriasumantri 2009). Kemampuan ini perlu dikembangkan dalam pembelajaran matematika, karena dapat membantu siswa untuk meningkatkan kemampuan pemahaman matematika (Priatna 2003). Dari sini dapat dikatakan bahwa upaya untuk meningkatkan kemampuan berpikir logis dapat menjembatani pada peningkatan hasil belajar matematika siswa melalui pemahaman yang benar terhadap konsep konsep matematika.

AdMathEdu | Vol.7 No.2 | Desember 2017 
Albrecht 1992 (dalam Saragi, 2011) menjelaskan bahwa dalam proses berpikir seseorang harus bertolak dari dalil logika, yakni: (a) dasar pemikiran atau realitas tempat berpijak, (b) argumentasi atau cara menempatkan dasar pemikiran bersama, dan (c) simpulan atau hasil yang dicapai dengan menerapkan argumentasi pada dasar pemikiran. Dalam matematika, proses untuk memperoleh kebenaran atau proses menarik kesimpulan dapat dilakukan dengan cara berpikir induktif dan deduktif.

Berpikir induktif atau induksi didefinisikan sebagai proses berpikir untuk menarik suatu kesimpulan dari halhal khusus ke hal yang umum, Sumarmo (dalam Saragi, 2011). Hal khusus yang dimaksud tersebut dapat berupa beberapa premis atau anteseden, sedangkan hal yang umum merupakan sebuah kesimpulan atau konklusi. Hal ini berarti bahwa proses berpikir induktif diawali dengan mengkaji premis-premis yang diberikan untuk memperoleh suatu persepsi tentang pola atau keteraturan, serta kesamaan sehingga diperoleh suatu kesimpulan. Karena proses pengambilan keputusan tersebut didasarkan pada pola, maka tidak tertutup kemungkinan kesimpulan yang diperoleh salah. Sumarmo (dalam Saragi, 2011) mengatakan bahwa berpikir induktif berhubungan dengan kebenaran kesimpulan yang bersifat probabilistik.

Saragih (2006) mengungkapkan bahwa berpikir logis mempunyai perbedaan dengan menghafal. Menghafal hanya mengacu pada pencapaian kemampuan ingatan belaka, sedangkan berpikir logis lebih mengacu pada pemahaman pengertian (dapat mengerti), kemampuan aplikasi, kemampuan analisis, kemampuan sintesis, bahkan kemampuan evaluasi untuk membentuk kecakapan (suatu proses). Menurut Albrecht (2009) dalam audiblox (Logical Thinking: A Learned Mental Process) menyatakan bahwa; "logical thinking is the process in which one uses reasoning consistently to come to a conclusion. Problems or situations that involve logical thinking call for structure, for relationships between facts, and for chains of reasoning that "make sense." Pemikiran logis adalah proses di mana penggunaan penalaran secara konsisten untuk mengambil sebuah kesimpulan. Permasalahan atau situasi yang melibatkan pemikiran logis mengharapkan struktur, hubungan antara fakta-fakta, dan menghubungkan penalaran yang "bisa dipahami."

Berpikir logis erat kaitannya dengan pemecahan masalah. Kemampuan berpikir logis diperlukan individu, 
pada saat beraktivitas dalam mengambil keputusan, menarik kesimpulan, dan melakukan pemecahan masalah. Bentuk aktivitas yang dilakukan dapat berkaitan dengan masalah matematis maupun masalah yang ditemukan dalam kehidupan sehari-hari. Aktivitas lain yang dilakukan individu dalam berpi kir logis adalah ketika menjelaskan mengapa dan bagaimana suatu hasil diperoleh, bagaimana cara menarik kesimpulan dari premis yang tersedia, dan menarik kesimpulan berdasarkan aturan inferensi tertentu. Bentuk aktivitas yang lebih luas dari kemampuan berpikir logis adalah menyelesaikan masalah secara masuk akal.

Pemecahan masalah yang sifatnya terbuka dibutuhkan proses berpikir mahasiswa yang komplit dan sistematis, yaitu dalam memunculkan alternatifalternatif jawaban yang benar atau memunculkan berbagai cara yang menuju ke satu jawaban benar dari masalah yang diberikan. Oleh sebab itu, dalam pembelajaran matematika dosen perlu mengetahui proses berpikir mahasiswa dalam menyelesaikan masalah, membantu mahasiswa untuk menyelesaikan masalah terbuka, dan mengembangkan keterampilan siswa dalam memonitoring dan mengevaluasi Analisis ... (Wahyuddin) pemikirannya sendiri ketika menyelesaikan masalah.

$$
\text { Berberapa hasil penelitian }
$$
terdahulu yang menjelaskan hubungan antara berpikir logis dengan pemecahan masalah diantaranya Bancong, 2013 dengan hasil penelitian bahwa profil penalaran logis peserta didik yang memiliki gaya berpikir berdampak pada kemampuan memecahkan masalah Fisika. Maharani, 2013 dengan hasil penelitian bahwa (1) Berpikir logis mahasiswa dalam memahami, merencanakan, menyelesaikan dan memeriksa kembali hasil yang diperoleh, mahasiswa berkemampuan tinggi pada tahap analisis membagi masalah ke dalam unsur atau sub masalah memiliki kecenderungan baik. Sedangkan, mahasiswa berkemampuan sedang dan rendah berkecenderungan cukup, (2) Berpikir logis mahasiswa dalam memahami, merencanakan, menyelesaikan dan memeriksa kembali hasil yang diperoleh, mahasiswa berkemampuan tinggi pada tahap analisis membuat diagram berpikir memiliki kecenderungan baik, sedangkan mahasiswa berkemampuan sedang dan rendah pada tahap analisis membuat diagram berpikir memiliki kecenderungan cukup, (3) Berpikir logis mahasiswa dalam merencanakan, 
menyelesaikan dan memeriksa kembali hasil yang diperoleh, mahasiswa berkemampuan tinggi pada tahap analisis mengumpulkan faktor memiliki kecenderungan baik, mahasiswa berkemampuan sedang kecenderungan cukup, dan mahasiswa berkemampuan rendah kecenderungan kurang, (4) Berpikir logis mahasiswa dalam merencanakan, menyelesaikan dan memeriksa kembali hasil yang diperoleh, mahasiswa berkemampuan tinggi, sedang dan rendah pada tahap analisis mencari hubungan memiliki kecenderungan baik, (5) Berpikir logis mahasiswa dalam merencanakan, menyelesaikan dan memeriksa kembali hasil yang diperoleh, mahasiswa berkemampuan tinggi, sedang dan rendah pada tahap analisis menemukan situasi memiliki kecenderungan baik, (6) Berpikir logis mahasiswa dalam menyelesaikan dan memeriksa kembali hasil yang diperoleh, mahasiswa berkemampuan tinggi dan sedang pada tahap analisis kesimpulan memiliki kecenderungan cukup. Sedangkan, mahasiswa berkemampuan rendah kecenderungan kurang, (7) Berpikir logis mahasiswa dalam memahami, merencanakan, menyelesaikan dan memeriksa kembali hasil yang diperoleh, mahasiswa berkemampuan tinggi dan sedang pada tahap analisis langkah-langkah sistematis memiliki kecenderungan cukup. Sedangkan, mahasiswa berkemampuan rendah kecenderungan kurang.

Banyaknya permasalahan tentang rendahnya kemampuan masalah mahasiswa diungkapkan oleh beberaaa penelitian sebelumnya. Hal ini sesuai dengan penyataan Kilpatrik (Nelvin, 2012) meskipun siswa memiliki konsep dan keterampilan yang dibutuhkan, namun siswa tidak selalu berhasil dalam menyelesaikan masalah matematika. Demikian pula, Siswono (2006) menjelaskan salah satu masalah dalam pembelajaran matematika adalah rendahnya kemampuan siswa dalam memecahkan masalah tidak rutin atau masalah terbuka. Salah satu faktor penyebabnya kemampuan siswa dalam pemecahan masalah adalah dalam merencanakan pemecahan masalah tidak dibahas strategi-strategi yang bervariasi untuk mendapatkan jawaban masalah.

Di tingkat perguruan tinggi, menurut CUPM (2004), mahasiswa seringkali secara keseluruhan tidak menyadari pentingnya hubunganhubungan antara subjek matematika yang terpisah dan antara matematika dengaan disiplin lainnya. Mereka juga secara mengejutkan enggan atau tidak dapat menerapkan pengetahuan yang mereka 
peroleh dalam pelajaran-pelajaran matematika kepada disiplin lainnya.

Namun kenyataannya, mahasiswa sebagian besar merasa kesulitan dalam menyelesaikan berbagai jenis permasalahan yang diberikan, apalagi jika harus berhadapan dengan soal-soal yang tidak rutin. Dari hasil wawancara, mahasiswa mengaku merasa bingung untuk menggunakan teori yang sesuai dengan permasalahan yang diberikan. Berdasarkan hasil pengamatan penulis pata tanggal 19 Oktober 2016 diperoleh informasih bahwa kelemahan mahasiswa dalam myelesaiakan masalah pada mata kuliah matematika ekonomi adalah tidak mengertinya mahasiswa terhapat suatu permasalahan sehingga tidak dapat mengidentifikasi dan menerapkan pendekatan dan strategi untuk menyelesaikan masalah; hal lain yaitu mahasiswa tidak mampu membuat suatu pemodelan matematika atau kurang mampu mentransfer suatu permasalahan yang berbentuk soal cerita menjadi sebuah kalimat matematika, disamping itu masih rendahnya pengetahuan matematis mahasiswa dalam pemecahan masalah.

Kesalahan lain yang dialami mahasiswa dalam menyelesaikan masalah pada bagian memahami masalah adalah kesalahan kebiasaan dan ketidakpahaman Analisis ... (Wahyuddin) terhadap soal, kesalahan interpretasi bahasa, dan kesalahan simbolik dan pemodelan matematika, kesalahan konse, kesalahan prinsip, dan kesalahan algoritma. Selain itu, mahasiswa tidak menguasai konsep-konsep sebelumnya yang digunakan dalam materi yang dipelajari dan kurangnya latihan dalam mengerjakan soal-soal logika sehingga kesalahan mahasiswa terutama pada keterampilan cukup banyak. Lebih lanjut, pemahaman atas keterkaitan logis antar konsep, teori, aspek teknik kurang ditekankan secara efektif sehingga mahasiswa cenderung menghafal, kurang kreatif, dan sulit mengembangkan kemampuan kognitifnya. (Fachrurrozie, 2009).

Pemahaman atas materi pada setiap mata kuliah mutlak diperlukan sebagai kerangka berpikir untuk memecahkan masalah tersebut. menghadapi masalah karena materi tersebut mengenalkan sesuatu yang baru dan kompleks untuk lingkup bahasa matematika untuk suatu keadaan atau mendekati permasalahan ekonomi. Masalah tersebut berdampak pada rendahnya keterlibatan mahasiswa dalam proses belajar mengajar. Mata kuliah Matematika Ekonomi memiliki materi yang cukup padat, yang membutuhkan ketajaman aspek kognitif 
dan kemampuan teknis matematika, sehingga diperlukan latihan-latihan soal, baik yang bersifat kasus ataupun tidak. Oleh karena itu penilaian terhadap mata kuliah ini tidak hanya didasarkan pada hasil akhir mahasiswa yang tercermin dari nilai ujian tertulis, tetapi lebih ditekankan pada kemampuan mahasiswa untuk melakukan proses yang sesuai dengan pedoman normatif yang berlaku. Penilaian terhadap proses pembelajaran mahasiswa didasarkan pada keaktifan dan keterlibatan mahasiswa selama perkuliahan, baik dalam memberikan saran, pertanyaan ataupun argumentasinya.

\section{Metode Penelitian}

Penelitian ini merupakan penelitian ex-post facto yang bersifat kausalitas dengan populasi sebanyak 245 orang yang berasal dari 8 kelas yang berbeda. Sampel sebanyak 59 orang yang berasal dari 2 kelas dengan teknik pengambilan sampel yaitu pengambilan sampel secara acak berkelompok. Instrumen penelitian terdiri atas tes kemampuan berpikir logis sebanyak 30 butir soal dan tes kemampuan pemecahan masalah sebanyak 5 butir soal yang dinyatakan valid dan reliabel sebelum digunakan.

Prosedur penelitian ini diawali dengan analisis situasi yang bermuara pada perumusan masalah dan penentuan tujuan penelitian yang dilakjutkan dengan pengumpulan data melalui tes kemampuan pemecahan masalah dan tes kemampuan berpikir logis. Teknik analisis data yang digunakan adalah statistika deskriptif dan analisis inferensial (Analisis Regresi). Analisis deskriptif berdasarkan persentase ketercapaian kemampuan pemecahan masalah dan kemampuan berpikir logis dengan rumus:

Persentase skor tiap mahasiswa $=\frac{\text { Jumlah Setiap Skor X } 100 \%}{\text { Jumlah Skor Ideal }}$

Persentase skor rata-rata mahasiswa = Jumlah Persentase Skor Seluruh Mahasiswa Jumlah Mahasiswa

Sebagai pedoman dalam mengambil keputusan/kesimpulan dari hasil analisis data dengan menggunakan persentase (\%) ditetapkan klasifikasi yang juga mengacu pada pendapat Arikunto (2002) sebagai berikut.

Tabel 1. Kriteria Persentase Kemampuan Pemecahan Masalah dan Kemampuan Berpikir Logis.

\begin{tabular}{ccc}
\hline No & Persentase\% & Klasifikasi \\
\hline $\mathbf{1}$ & $92-100$ & Baik Sekali \\
$\mathbf{2}$ & $75-91$ & Baik \\
$\mathbf{3}$ & $50-74$ & Cukup Baik \\
$\mathbf{4}$ & $25-49$ & Kurang Baik \\
$\mathbf{5}$ & $0-24$ & Tidak Baik \\
\hline \multicolumn{3}{c}{ Sumber: Arikunto (2002) }
\end{tabular}

\section{Hasil Dan Pembahasan}


Hasil penelitian dianalisis dengan dua metode, yaitu analisis deskritif dan analisis infrensial dengan hasil sebagaimana tabel berikut.

1. Hasil Analisis Deskriptif

Tabel 2. Hasil Analisis Deskriptif

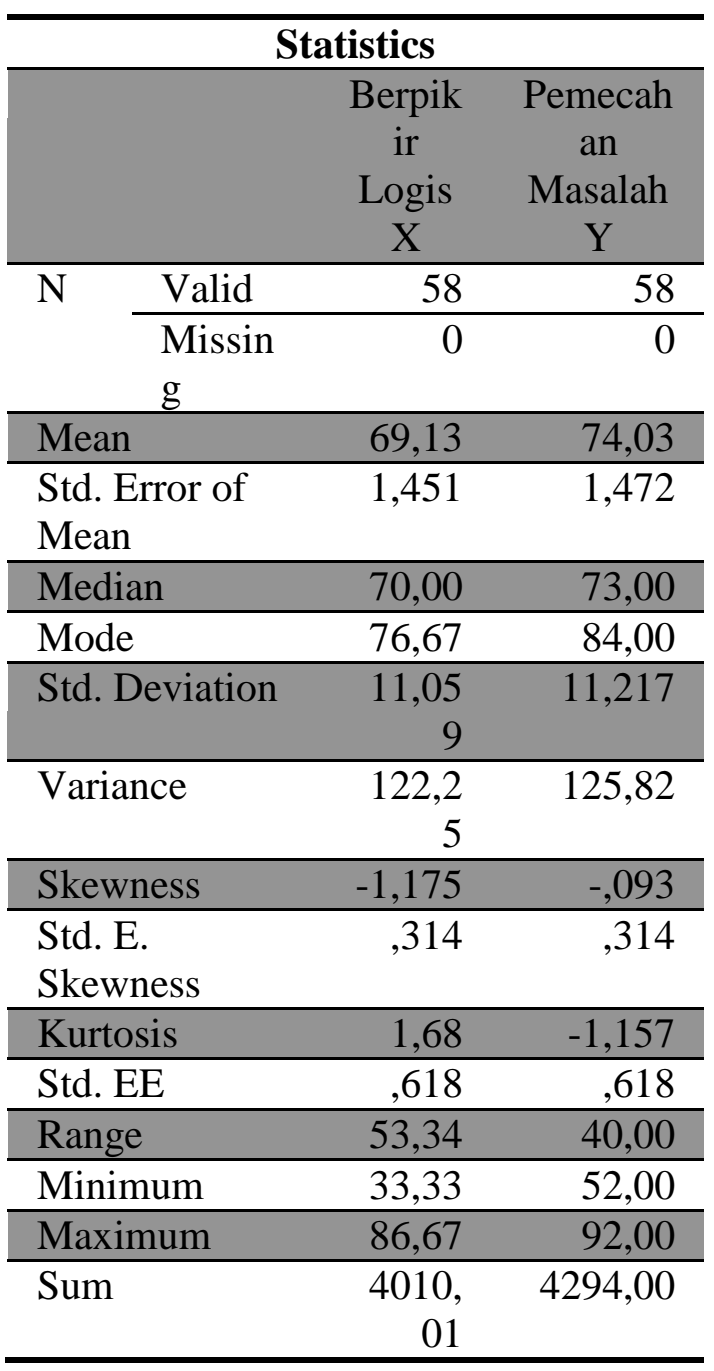

Sumber : Data Diolah

Selanjutnya hasil kemampuan berpikir logis dan kemampuan pemecahan masalah dikasifikasikan pada tabel berikut.
Tabel 3. Klasisfikasi Kemampuan Berpikir Logis

\begin{tabular}{cccc}
\hline No & Keterangan & $\boldsymbol{f i}$ & $\mathbf{\%}$ \\
\hline $\mathbf{1}$ & Baik Sekali & 0 & 0 \\
$\mathbf{2}$ & Baik & 37 & 63,79 \\
$\mathbf{3}$ & Cukup Baik & 18 & 31,03 \\
$\mathbf{4}$ & Kurang Baik & 3 & 5,17 \\
$\mathbf{5}$ & Tidak Baik & 0 & 0 \\
$\mathbf{6}$ & Jumlah & 58 & 100 \\
\hline
\end{tabular}

Sumber : Data Diolah

Tabel 4. Klasisfikasi Kemampuan Pemecahan Masalah

\begin{tabular}{cccc}
\hline NO & Keterangan & $\boldsymbol{f i}$ & $\mathbf{\%}$ \\
\hline $\mathbf{1}$ & Baik Sekali & 2 & 3,45 \\
$\mathbf{2}$ & Baik & 22 & 37,93 \\
$\mathbf{3}$ & Cukup Baik & 34 & 58,62 \\
$\mathbf{4}$ & Kurang Baik & 0 & 0 \\
$\mathbf{5}$ & Tidak Baik & 0 & 0 \\
$\mathbf{6}$ & Jumlah & 55 & 100 \\
\hline Sumber $:$ Data Diolah & &
\end{tabular}

Tabel 5. Profil keterkaitan anatara kemampuan berpikir logis dengan kemampuan pemecahan masalah.

\begin{tabular}{|c|c|c|c|}
\hline No & Keterangan & $f i$ & $\%$ \\
\hline 1 & Kurang -> Baik & 1 & 1,72 \\
\hline 2 & Cukup -> Baik & 11 & 18,97 \\
\hline 3 & $\begin{array}{c}\text { Kurang -> Cukup } \\
\text { Baik }\end{array}$ & 2 & 3,45 \\
\hline 4 & $\begin{array}{l}\text { Cukup Baik -> } \\
\text { Cukup Baik }\end{array}$ & 24 & 41,38 \\
\hline 5 & $\begin{array}{c}\text { Baik -> Cukup } \\
\text { Baik }\end{array}$ & 8 & 13,79 \\
\hline 6 & Baik -> Baik & 10 & 17,24 \\
\hline 8 & $\begin{array}{c}\text { Cukup Baik -> } \\
\text { Baik Sekali }\end{array}$ & 2 & 3,45 \\
\hline 9 & Jumlah & 58 & 100 \\
\hline
\end{tabular}

Sumber : Data Diolah

2. Hasil Analisis Infrensial 
Analisis infrensial dengan metode

sebagaimana

tabel

berikut.

analisis regresi sederhana diperoleh hasil

Tabel 6. Hasil Analisis Regresi

\begin{tabular}{|c|c|c|c|c|}
\hline No & Model & & Nilai & \\
\hline 1 & $\overline{\mathrm{R}}$ & &, $945^{\mathrm{a}}$ & \\
\hline 2 & R Square & & ,893 & \\
\hline 3 & $\begin{array}{c}\text { Adjusted R } \\
\text { Square }\end{array}$ & & ,891 & \\
\hline 4 & Std. EE & & ,81784 & \\
\hline 5 & $\mathrm{~F}$ & & 465,132 & \\
\hline 6 & Sig. & &, $000^{\mathrm{b}}$ & \\
\hline & Costant & & 1,695 & \\
\hline 8 & Ket & Beta & $\mathrm{t}$ & Sig \\
\hline 9 & BerpikirLogis $\mathrm{X}$ & 0,704 & 21,56 & 0,00 \\
\hline 9 & Jumlah & 58 & 100 & \\
\hline
\end{tabular}

Model Summary

- Angka R sebesar 0.945 menunjukkan bahwa korelasi nilai pengamatan dan nilai prediksi cukup kuat.

- Angka $R$ square atau koefisien determinasi adalah 0.893. Hal ini berarti bahwa model mempunyai daya ramal 89,3\% variasi Y dijelaskan oleh model. Hal tersebut diartikan bahwa kemampuan berpikir logis pengaruh sebesar $89,3 \%$ terhadap terhadap kemampuan pemecahan masalah mahasiswa.

- Adjusted R Square yaitu 8,91. Hal ini berarti $89,1 \%$ variasi dari variabel terikat bisa dijelaskan oleh variasi dari
Sumber : Data Diolah

variabel bebas, sedangkan sisanya $10,9 \%$ dijelaskan oleh variabel lain di luar model.

- Standard Error of Estimate (SEE) adalah 0,817 Makin kecil SEE akan membuat model regresi semakin tepat memprediksi variabel terikat.

Hasil persamaan regresi yang diperoleh sebagai berikut:

$$
\mathrm{Y}=1,69+0,704 \mathrm{X}
$$

Berdasarkan hasil penelitian diperoleh rata-rata skor kemampuan berpikir logis dari 58 responden sebesar 69,13 atau berada pada kategori cukup baik dengan keterangan bahwa 3 orang atau 5,17\% berapa dapa kategori kurang 
baik, 18 atau 31,03\% berada pada kategori cukup baik, 37 atau 63,79\% berada pada kategori baik, dan tidak ada yang berada pada kategori kurang baik dan tidak baik.

Skor kemampuan pemecahan masalah dari 58 responden gengan ratarata skor sebesar 74,03 atau berada pada kategori cukup baik dengan keterangan bahwa 2 orang atau 3,45\% berapa dapa kategori sangat baik, 22 atau 37,93\% berada pada kategori baik, 34 atau $58,62 \%$ berada pada cukup baik, dan tidak ada yang berada pada kategori kurang baik dan tidak baik.

Selanjutnya dari hasil analisis korelasi diperoleh nilai Pearson Correlation sebesar 0,945 dengan nilai sig. $=0.000<0.05$ hal tersebut diartikan bahwa kemampuan berpikir logis memiliki korelasi dengan kemampuan penyelesaian masalah matematika dengan besar hubungan $94,5 \%$ dimana hal tersebut berada pada kategori baik sekali. Lebih lanjut hasil analisis deskriptif dapat dijelaskan bahwa dari 58 mahasiswa terdapat 1 orang atau $1,72 \%$ mahasiswa yang memiliki kemampuan berpikir logis berada pada kategori kurang baik namun memiliki kemampuan penyelesaian masalah berada pada kategori baik; 1 orang atau $18,97 \%$ mahasiswa yang memiliki kemampuan berpikir logis Analisis ... (Wahyuddin) berada pada kategori cukup baik namun memiliki kemampuan penyelesaian masalah berada pada kategori baik; 2 orang atau $3,45 \%$ mahasiswa yang memiliki kemampuan berpikir logis berada pada kategori kurang baik namun memiliki kemampuan penyelesaian masalah berada pada kategori cukup baik; 24 orang atau $41,38 \%$ mahasiswa yang memiliki kemampuan berpikir logis berada pada kategori cukup baik namun kemampuan penyelesaian masalahnya juga berada pada kategori cukup baik; 8 orang atau $13,79 \%$ mahasiswa yang memiliki kemampuan berpikir logis berada pada kategori baik namun kemampuan penyelesaian masalahnya juga berada pada kategori cukup baik; 10 orang atau $17,24 \%$ mahasiswa yang memiliki kemampuan berpikir logis berada pada kategori baik dan kemampuan penyelesaian masalahnya juga berada pada kategori baik; dan 2 orang atau $3,45 \%$ mahasiswa yang memiliki kemampuan berpikir logis berada pada kategori cukup baik namun memiliki kemampuan penyelesaian masalah berada pada kategori baik sekali.

Lebih lanjut kemampuan berpikir logis berpengaruh positif terhadap kemampuan penyelesaian masalah dengan pengaruh sebesar 89,1\% sedangkan sisanya sebesar $10,9 \%$ 
dipengaruhi oleh variabel lain di luar model. Kemampuan berpikir logis berpengaruh positif terhadap kemampuan kemampuan penyelesaian, hal tersebut dapat diartikan bahwa semakin baik atau semakin tinggi kemampuan berpikir logis yang dimiliki oleh mahasiswa maka kemampuan penyelesaian masalah mahasiswa tersebut akan semakin baik atau semakin tinggi.

Hal tersebut menjadi dasar bahwa kemampuan berpikir logis amatlah penting dimiliki oleh mahasiswa, lebih lanjut dijelaskan bahwa orang yang dapat memecahkan masalah secara kompleks memiliki kemampuan pemikiran dan penalaran logis yang cukup. Berpikir logis mampu mempertanyakan memproses evaluasi yang diwujudkan dalam pemecahan masalah (Nazan, 2011). Pemikiran logis adalah salah satu cara yang digunakan dalam memperoleh aktivitas mental canggih. Dengan demikian, kemampuan merupakan kegiatan tingkat aplikasi yang tergantung pada tingkat pengetahuan dan pemahaman tujuan, pemikiran logis dalam mengevaluasi ide, informasi dan pengalaman.

Hasil penelitian ini sejalan dengan hasil penelitian Bancong, 2013 dengan hasil penelitian bahwa profil penalaran logis peserta didik yang memiliki gaya berpikir berdampak pada kemampuan memecahkan masalah Fisika. Maharani, 2013 dengan hasil penelitian bahwa (1) Berpikir logis mahasiswa dalam memahami, merencanakan, menyelesaikan dan memeriksa kembali hasil yang diperoleh, mahasiswa berkemampuan tinggi pada tahap analisis membagi masalah ke dalam unsur atau sub masalah memiliki kecenderungan baik. Sedangkan, mahasiswa berkemampuan sedang dan rendah berkecenderungan cukup, (2) Berpikir logis mahasiswa dalam memahami, merencanakan, menyelesaikan dan memeriksa kembali hasil yang diperoleh, mahasiswa berkemampuan tinggi pada tahap analisis membuat diagram berpikir memiliki kecenderungan baik, sedangkan mahasiswa berkemampuan sedang dan rendah pada tahap analisis membuat diagram berpikir memiliki kecenderungan cukup.

Berpikir logis erat kaitannya dengan pemecahan masalah. Kemampuan berpikir logis diperlukan individu, pada saat beraktivitas dalam mengambil keputusan, menarik kesimpulan, dan melakukan pemecahan masalah. Bentuk aktivitas yang dilakukan dapat berkaitan dengan masalah matematis maupun masalah yang ditemukan dalam kehidupan sehari-hari. Aktivitas lain yang dilakukan individu dalam 
berpi kir logis adalah ketika menjelaskan mengapa dan bagaimana suatu hasil diperoleh, bagaimana cara menarik kesimpulan dari premis yang tersedia, dan menarik kesimpulan berdasarkan aturan inferensi tertentu. Bentuk aktivitas yang lebih luas dari kemampuan berpikir logis adalah menyelesaikan masalah secara masuk akal.

Melalui pemecahan masalah terstruktur, mahasiswa diharapkan memperoleh pengalamanbelajar dalam menjelaskan setiap langkah atau manipulasi matematika yang mereka gunakan. Dengan mendorong keterlibatan mental mahasiswa secara mendalam dalam kegiatan pemecahan masalah, mahasiswa diharapkan mahasiswa dapat mengembangkan penalaran mereka (Scusa \& Yuma, 2008).

Hasil penelitian ini mendukung teori Munro 1994 yang menjelaskan bahwa kemampuan berpikir logis matematis adalah pemahaman dengan menggunakan konsep-konsep abstrak dan simbol seperti simbol matematika dan penalaran. Siswa membangun gagasan menggunakan penalaran induktif dan deduktif. Mereka mencari alasan logis, keteraturan dan konsistensi, caracara ide-ide terorganisir atau terkait, misalnya, sebab dan akibat. Mereka Analisis ... (Wahyuddin) menganalisis pola, membuat tujuan observasi, menarik kesimpulan dan merumuskan hipotesis serta menerapkan aturan umum untuk situasi tertentu. Mereka mudah memahami dan menggunakan rumus matematika, serta mereka lebih memilih hal yang terorganisir dan logis.

Hal tersebut menegaskan bahwa kemampuan berpikir logis matematis berkaitan erat dengan penalaran, baik induktif maupun deduktif. Selain itu kemampuan berpikir logis matematis juga sangat berpengaruh terhadap penarikan kesimpulan, dan menerapkan aturan umum (generalisasi), yang semuanya termasuk pada indikator kemampuan penalaran matematika.

Lebih lanjut menurit teori lain yang sejalan dengan hasil penelitian ini adalah Campbell (2006: 40) yang menyatakan bahwa kemampuan berpikir logis melibatkan banyak komponen yaitu antara lain sebagai berikut : (1) perhitungan secara matematis; berpikir logis; (3) pemecahan masalah; (4) pertimbangan deduktif dan induktif; dan (5) ketajaman pola-pola dan hubungan-hubungan. Dan teori Hoerr (2007: 18) yang menyatakan bahwa siswa yang mempunyai kemampuan berpikir logis menyukai hal-hal dibawah ini antara lain sebagai berikut : (1) Bekerja dengan AdMathEdu | Vol.7 No.2 | Desember 2017 
angka; (2) memecahkan masalah; (3) menganalisis situasi; (4) memahami cara kerja sesuatu; dan (5) memperlihatkan ketepatan dalam menyelesaikan masalah.

\section{Kesimpulan}

Berdasarkan hasil penelitian, maka ditarik simpulan sebagai berikut:

1. Tingkat kemampuan berpikir logis masiswa berada pada kategori cukup baik dengan nilai rata-rata 69,13 .

2. Tingkat kemampuan penyelesaian masalah matematika ekonomi bagi masiswa berada pada kategori cukup baik dengan nilai rata-rata 74,03.

3. Tingkat kemampuan berpikir logis masiswa memiliki korelasi dengan kemampuan penyelesaian masalah matematika ekonomi dengan besar hubungan $94,5 \%$ dimana hal tersebut berada pada baik sekali.

4. Hasil analisis deskriptif dapat dijelaskan bahwa dari 58 mahasiswa terdapat 1 orang atau $1,72 \%$ mahasiswa yang memiliki kemampuan berpikir logis berada pada kategori kurang baik namun memiliki kemampuan penyelesaian masalah berada pada kategori baik; 1 orang atau 18,97\% mahasiswa yang memiliki kemampuan berpikir logis berada pada kategori cukup baik namun memiliki kemampuan penyelesaian masalah berada pada kategori baik; 2 orang atau 3,45\% mahasiswa yang memiliki kemampuan berpikir logis berada pada kategori kurang baik namun memiliki kemampuan penyelesaian masalah berada pada kategori cukup baik; 24 orang atau $41,38 \%$ mahasiswa yang memiliki kemampuan berpikir logis berada pada kategori cukup baik namun kemampuan penyelesaian masalahnya juga berada pada kategori cukup baik; 8 orang atau $13,79 \%$ mahasiswa yang memiliki kemampuan berpikir logis berada pada kategori baik namun kemampuan penyelesaian masalahnya juga berada pada kategori cukup baik; 10 orang atau $17,24 \%$ mahasiswa yang memiliki kemampuan berpikir logis berada pada kategori baik dan kemampuan penyelesaian masalahnya juga berada pada kategori baik; dan 2 orang atau 3,45\% mahasiswa yang memiliki kemampuan berpikir logis berada pada kategori cukup baik namun memiliki kemampuan penyelesaian masalah berada pada kategori baik sekali.

5. Kemampuan berpikir logis berpengaruh positif terhadap kemampuan penyelesaian masalah dengan pengaruh sebesar $89,1 \%$ sedangkan sisanya sebesar $10,9 \%$ dipengaruhi oleh variabel lain di luar 
model. Kemampuan berpikir logis berpengaruh positif terhadap kemampuan kemampuan penyelesaian, hal tersebut dapat diartikan bahwa semakin baik atau semakin tinggi kemampuan berpikir logis yang dimiliki oleh mahasiswa maka kemampuan penyelesaian masalah mahasiswa tersebut akan semakin baik atau semakin tinggi.

\section{Pustaka}

Albrecht, K. (2009). Logical Thinking. http://www.audiblox2014.com/.

Alexander, K.D. (2007). Effect of Intruction in Creative Problem Solving on Cognition, Creativity, and Satisfaction among Ninth Grade Students in An Introduction to World Agricultural Science and Technology Course. Dissertation. The Graduate Faculty of Texas Teach University. (Online) Tersedia: http://www.scirus.com.

Arikunto, Suharsimi. (2002). Prosedur Penelitian Suatu Pendekatan Praktek. Jakarta: PT. Rineka Cipta.

Bancong, H. (2013). Profil Penalaran Logis Berdasarkan Gaya Berpikir dalam Memecahkan Masalah Fisika Peserta Didik. Jurnal Pendidikan IPA Indonesia. 2 (2), hlm. 195-202. ISSN: 2339-1286. Diakses di http ://journal.unnes.ac.id /nju/index.php/jpii.

Cambell, Linda. (2006). Metode Praktis pembelajaran Berbasis Multiple Intelligences. Depok : Insuisi Press.

Analisis ... (Wahyuddin)
CUPM (2004). Undergrad uate Program and Course in the Mathematical Sciences: CUPM Curriculum Guide. The Mathematical Association of America.

Departemen Pendidikan Nasional. (2005). Undang-Undang Nomor 14 Tahun 2005, Tentang Guru dan Dosen, Jakarta: Depdiknas.

Fachrurrozie. (2009). Eams Games Tournament Sebagai Upaya Peningkatan Kemampuan Belajar Mahasiswa Pada Mata Kuliah Matematika Ekonomi. Jurnal Pendidikan Ekonomi. 4 (1), hlm. 51-68. ISSN: 2541-562X. Diakses di

http://id.portalgaruda.org/?ref=bro wse \&mod=viewarticle $\&$ article $=13$ $\underline{6358 .}$.

Hoerr, Thomas. R. (2007) Buku Kerja Multiple Intelle Gences : Pengalaman New City School di St. Louis, Missouri, As, Dalam Menghargai Aneka Kecerdasan Anak. Bandung : Mizan Media Utama.

Kisworo, A. (2000). Pembelajaran Pemecahan Masalah pada Pembelajaran Geometri di Kelas I SMU Petra 5 Surabaya. Tesis. Surabaya : PPS Universitas Negeri Surabaya.

Matlin, M.W. (2003). Cognition. Fifth Edition. New York : John Wiley \& Son.Inc

Maharani, Swasti. (2013). Profil Berpikir Logis Mahasiswa Calon Guru Matematika dalam Menyelesaikan Luas Daerah dengan Menggunakan Integral Lipat Dua. Jurnal Ilmiah Pendidikan Matematika. 2 (1), hlm. 1-6. ISSN : 2301-7929. Diakses di 
http://e-

journal.ikippgrimadiun.ac.id/index. php/jipm/index.

Nazan, Sezen, (2011). A scale on logical thinking abilities. Procedia Social and Behavioral Sciences. 15 (2011), hlm. 2476-2480

NCTM. (2000). Principles and Standards for School Mathematics . Virginia: NCTM, Inc

Nelvin, Nool. R. (2012). Effectiveness of an Improvised Abacus in Teaching Addition of Integers. Journal of International Conference on Education and Management Innovation IPEDR..30 (2012), hal 307-311. Diakses di http://www.ipedr.com/vol30/60ICEMI\%202012-M10060.pdf.

Priatna, N. (2003). Kemampuan Penalaran dan Pemahaman Matematika Siswa Kelas 3 Sekolah Lanjutan Tingkat Pertama Negeri di Kota Bandung. Disertasi Doktor. PPS UPI Bandung: tidak diterbitkan.

Ruseffendi, E.T. (2006). Pengantar Kepada Membantu Guru Mengembangkan Kompetensinya dalam Pengajaran Matematika untuk Meningkatkan CBSA. Bandung: Tarsito.

Saragih, Sahat. (2006). Menumbuhkembangkan Berpikir Logis dan Sikap Positif terhadap Matematika Melalui Pendekatan Matematika Realistik. Jurnal pendidikan dan kebudayaan Departemen Pendidikan Nasional. Badan Penelitian dan Pengembangan, Edisi Juli 2006.

Saragih, S. (2011). Menumbuh Kembangkan Berpikir Logis dan
Sikap Positif Terhadap Matematika Melalui Pendekatan Matematika Realistik. Diakses di. www. Scribd. Com/ doc /4674 9184/aretical. Diakses pada 15 Oktber 2016.

Scusa, T. and Yuma, C.O. (2008). Five Processes of Mathematical Thinking: Math in the Middle Institute Partnership. University Of Nebraska Lincoln: Summative Projects For Ma Degree

Siswono, Tatag. (2004). Identifikasi

Proses Berpikir Kreatif Siswa dalam Pengajuan Masalah (Problem Posing) Matematika Berpandu dengan Model Wallas dan Creative Problem Solving (CPS). Buletin Pendidikan Matematika. 6 (2), hlm. 1-16. Diakses di https://tatagyes.files.wordpress.com /2009/11/paper04_wallascps1.pdf.

Sumarmo, U. (2000). Pengembangan Model Pembelajaran Matematika untuk Meningkatkan Kemampuan Inteleqtual Tingkat Tinggi Siswa Sekolah Dasar. Laporan Penelitian FPMIPA IKIP Bandung. Tidak diterbitkan. (1994). Suatu Alternatif Pengajaran untuk Meningkatkan Kemampuan Pemecahan Masalah Matematika pada Guru dan Siswa SMP. Bandung: Pendidikan Matematika FPMIPA Bandung.

Suriasumantri, J.S. (2009). Filsafat Ilmu Sebagai Pengantar Populer . Jakarta : Pustaka Sinar Harapan.

Utari, Sumarmo. (2003). Berpikir dan Disposisi Matematik: Apa, Mengapa, dan Bagaimana dikembangkan pada Siswa Sekolah Dasar dan Menengah. Bandung: ITB. 
Walle, John A. Van De. (2008).

Sekolah Dasar dan Menengah

Matematika Pengembangan

Pengajaran . Jakarta: Erlangga.

Van De Walle, John A. (2003).

Pengembangan Pengajaran

Matematika. Jakarta: Erlangga. 